\title{
FACTORS THAT AFFECT THE E-LOYALTY FOR AIRLINE COMPANIES' PAGES ON SOCIAL MEDIA SITES
}

\section{DOI: 10.17261/Pressacademia.2015312955}

\author{
Seda Arslan', Ozlem Atalik ${ }^{2}$ \\ ${ }^{1}$ Iskenderun Technical University, sedaarslan@mku.edu.tr \\ ${ }^{2}$ Anadolu University, oatalik@anadolu.edu.tr
}

\section{Keywords}

Airline industry, airline company, social media sites, e-loyalty, Turkey

\section{JEL Classification}

L81, L82, L93, M31

\begin{abstract}
Nowadays, along with the rapid developments in the field of technology, marketing plans and activities of companies have started to reshape accordingly. This reshape introduced the social media sites, thus an interactive communication environment occurred between the companies and customers. Under these circumstances, airline companies couldn't be indifferent and they also carried their operations into this media environment. In this regard, this study focuses on finding out the interrelationship among the items such as social presence, interaction, switching cost, member profile and sense of belonging that are thought to be effective on the efforts to create e-loyalty. Surveys were conducted on 490 people who follow the Facebook and Twitter Pages of airline companies that operate in Turkey. For the purpose of data analysis, Mann-Whitney $U$, Kruskal Vallis and correlation analysis methods were used.According to the survey results; it has been concluded that social presence, interaction, switching costs, member profile and sense of belonging effect e-loyalty positively.
\end{abstract}

\section{HAVAYOLU IŞLETMELERININ SOSYAL MEDYA SITELERINDEKI SAYFALARINA YÖNELIK ELEKTRONIK SADAKATI ETKILEYEN UNSURLAR*}

\section{Anahtar Kelimeler \\ Pazarlama, marka, reklam, Rossiter Percy Izgarası, sosyal ağ.}

\section{JEL Sınıflandırması} L81, L82, L93, M31

\section{ÖZET}

Günümüzde teknoloji alanında yaşanan hızlı gelişmelerle beraber, işletmelerin pazarlama plan ve faaliyetleri bu doğrultuda yeniden şekillenmeye başlamıştır. Bu yeni şekillenme, sosyal medya sitelerini ortaya çıkarmış ve bu sayede işletmelerle müşteriler arasında interaktif bir iletişim ortamı oluşmuştur. Bu duruma havayolu işletmeleri de kayıtsız kalamamış ve bu medya ortamına işlemlerini taşımaya yönlendirmiştir. Bu bağlamda çalışma; havayolu işletmelerinin sosyal medya sitelerinde yer alan sayfalarında, elektronik sadakat yaratma çabaları üzerinde etkili olduğu düşünülen; sosyal bulunuşluk, etkileşim, değişim maliyeti, üye profili ve aidiyet duygusu ile olan ilişkisini ortaya çıkarmaya odaklanmaktadır. Anketler, Türkiye'de faaliyet gösteren havayolu işletmelerinin, sosyal paylaşım siteleri olan Facebook ve Twitter'daki sayfalarını takip eden 490 kişiye uygulanmıştır. Verilerin analizi amacıyla Mann-Whitney $U$, Kruskal Vallis ve Korelasyon Analizi yöntemleri kullanılmıştır. Araştırma sonuçlarına göre; sosyal bulunuşluk, etkileşim, değişim maliyeti, üye profili ve aidiyet duygusu ile e-sadakat arasında pozitif bir ilişki olduğu sonucuna ulaşılmıştır.

\footnotetext{
* Bu makale Doç. Dr. Özlem ATALIK'ın danışmanlığında Seda ARSLAN'ın Anadolu Üniversitesi Sosyal Bilimler
} Enstitüsünde hazırladığı tezden üretilmiştir. 


\section{GiRiş}

Sosyal medya, alışkanlık ve ihtiyaç haline gelen, her türlü ortam, eğitim seviyesi ve kültürden kullanıcıların taleplerine yanıt verebilen bir ortam olmakla birlikte; sürekli güncellenen, çoklu kullanıma açık, birey ya da işletmelerin istedikleri zaman, istedikleri bilgi, düşünce, fotoğraf ya da videoları paylaşmalarına olanak tanıyan platformlardır (Vural ve Bat, 2010: 3349). Bu paylaşımlar, sosyal medyanın çeşitli araçları vasıtasıyla gerçekleşebilmektedir. Sosyal medya araçlarına yönelik farklı sınıflandırmalar olsa da, temelde; bloglar, mikro bloglar ve Twitter, wikiler, sosyal işaretleme, içerik paylaşım toplulukları, podcastler, sanal dünyalar, RRS, forumlar ve sosyal ağ siteleri şeklindedir (Akar, 2010: 21). Gerek bireysel gerekse ticari anlamda en fazla kullanılan sosyal medya araçları; Twitter ve sosyal ağlardan biri olan Facebook'tur http://eticaretmag.com/sosyalmedya-ve-mobil-istatistikleri.

Son yıllarda, özellikle mobil teknolojilerinde yaşanan gelişim, bilgi ve iletişim teknolojilerine olan artan güven, kullanıcı dostu programlar, çift taraflı etkileşim ve sosyal ilişkilere dayalı iletişim gibi nedenlerle, insanların sosyal ağ sitelerinde geçirdikleri zaman artmıştır ve günlük yaşamın bir parçası haline gelmiştir (Akar, 2010: 113-114). Örneğin; 7 milyar olan dünya nüfusunun, yaklaşık 1,85 milyarı sosyal medyayı kullanmakta olup, bu platformlarda ortalama günlük 2 saatlerini geçirmektedir. Türkiye'de ise, 35 milyonun üzerinde kişi, herhangi bir sosyal medya sitesine üye olup, ortalama 2,5 saatlerini sosyal medya sitelerinde geçirmektedir.

Kişisel kullanıcıların sosyal ağ uygulamalarına yoğun ilgi göstermesi, işletmelerin de faaliyetlerini bu ortama taşımalarına neden olmuştur. 2013 yılında, Amerika, Ingiltere, Kanada ve Avustralya'da faaliyet gösteren 3000 büyük, orta ve küçük ölçekli işletmelerle, sosyal ağ siteleri üzerinden gerçekleştirdikleri pazarlama faaliyetlerine yönelik bir araştırma yapılmıştır. Buna göre, araştırmaya katılan işletmelerin \%97'si sosyal medya pazarlamasını kullanmakta olup, \%86'sı sosyal medyanın işletmeler için oldukça önemli olduğunu vurgulamıştır. Araştırmaya katılan işletmelerin \%47'si, 2 yıldan fazla bir süredir sosyal ağ sitelerini, pazarlama amaçlı kullandığını ifade etmiş olup; \% 62'si haftalık 6 saat ve fazla, \% 36'sı ise haftalık 11 saat ve daha fazla zamanı sosyal ağ sitelerinde geçirmektedir (Stelzner, 2013: 3-14). İşletmeler; ağızdan ağıza iletişimi desteklemek, pazar araştırması yapmak, genel pazarlama faaliyetlerini gerçekleştirmek, yeni ürün ya da hizmet geliştirmek, müşteri hizmetlerini sağlamak, markalarına yönelik itibarlarını yönetmek amacıyla, sosyal ağlarda yer alabilmektedir (Akar, 2010: 126). Örneğin Delta Havayolları, Facebook üzerinden bilet satışı gerçekleştirmek suretiyle, sosyal ağlar üzerinden pazarlama faaliyetlerini yürütmektedir (Eröz ve Doğdubay, 2012: 145). Bir kişinin Facebook üzerinden reklamı yapılan bir markayı takip ederek, hayranı olması ve bunu arkadaşlarının görmesine izin vermesi, kişilerin markaya yönelik algılamalarını olumlu yönde etkileyebilmektedir (Smillie, 2010). Golletz ve Ogheden'in (2010: 24) çalışmalarında, Facebook'ta yer alan bir markanın ortalama 10.000 hayranı varsa, bu markanın ismi ortalama 1.3 milyon -1.5 milyon kişiye ulaşabilecektir. İşletmelerin Facebook üzerinden yapmış oldukları reklam çalışmaları neticesinde ise, resmi internet sitelerine olan trafiğin, \%10 - 20 oranında artış yaşanabileceği öngörülmüştür.

Sosyal medya uygulamalarının işletmelerce etkin ve verimli bir şekilde kullanılamaması; söz konusu uygulamaların sunduğu olanaklardan tam manasıyla yararlanılamamasına ve 
müşterilerle etkileşime geçememesine neden olabilmektedir. Bu durum işletmelerin, sosyal ağ sitelerindeki sayfalarına yönelik sadık müşteri sayısını azaltabilmekte, müşterilere kötü hizmet sunma riskini oluşturabilmekte ve dolayısıyla işletmeye olumsuz etkiler oluşturabilmektedir (Bulunmaz, 2011: 29-30; Golletz ve Ogheden, 2010: 25).

İşletmelerin kurumsal internet sitelerine yönelik e-sadakati etkileyen faktörleri belirlemeye yönelik, gerek ulusal gerekse uluslararası literatürde çeşitli araştırmalar yapılmış olsa da (Guo ve Liu, 2010; Lin, 2008; Al-Maghrabi, 2011; Mouakket ve Al-hawari, 2012; Llach vd., 2013; Elkhani vd., 2014; Forgas vd., 2012); havayolu işletmelerinin sosyal paylaşım sitelerindeki sayfalarında e-sadakati oluşturabilecek unsurların neler olabileceğine dair çalışmalar (Nusair, 2013; Currás-Pérez vd., 2013) nispeten azdır. Bu nedenle bu çalışmada, havayolu işletmelerinin Facebook, Twitter gibi sosyal paylaşım sitelerindeki sayfalarına yönelik e-sadakatin oluşumuna katkı sağlayabilecek unsurlar ve bu unsurların e-sadakat üzerindeki etkileri araştırımıştır. Bu amaç çerçevesinde araştırmada cevaplanmak istenen soruların aşağıdaki biçimde sıralanması mümkündür:

1. Sosyal medya sitelerinde sayfaları bulunan havayolu işletmelerinin, bu sayfaları takip eden mevcut ve/veya potansiyel müşterilerinin, bu sayfalara karşı sadakat (elektronik sadakat) göstermekte midir?

2. Sosyal medya sitelerinde sayfaları bulunan havayolu işletmelerinin sayfalarına yönelik elektronik sadakat oluşumuna katkı sağlayabilecek değişkenler nelerdir?

3. Sosyal medya sitelerinde sayfaları bulunan havayolu işletmelerinin sayfalarına yönelik elektronik sadakat oluşumuna katkı sağlayabilecek değişkenlerin, esadakat üzerindeki etkisi nasıldır?

4. Cinsiyet, yaş, medeni durum, eğitim durumu, aylık ortalama gelir, internet kullanım süresi, internet kullanım sıklığı, sosyal paylaşım sitelerinde sayfaları bulunan ve takip edilen havayolu işletmesi ve havayolu işletmelerinin sosyal medya sitelerindeki sayfaların kullanım sıklığı tarafından oluşturulan demografik değişkenler ile elektronik sadakat arasında anlamlı bir fark var mıdır?

\section{LITERATÜR ARAŞTIRMASI}

Bu bölümde, sosyal paylaşım sitelerinde e-sadakat, sosyal bulunuşluk, etkileşim, değişim maliyeti, üye profili ve aidiyet duygusu ile ilgili bilgiler verilecek ve daha sonra bu değişkenler ile e-sadakat arasındaki ilişkiden bahsedilecektir.

\subsection{Elektronik Sadakat}

Son yıllarda yaşanan küreselleşme ve gelişen teknolojiyle beraber, sınırlar ortadan kalkmış, kişi ya da kurumlar, dünyanın diğer ucundaki işletmelerden mal ya da hizmet satın alabilir hale gelmiştir. Dolayısıyla bu ortamda işletmeler arasında yaşanan rekabet artmış, yeni müşteri kazanmak ve bu müşterileri işletmeye karşı sadık hale getirmek daha önemli hale gelmiştir. Çünkü yeni bir müşteri kazanmanın maliyeti, eski müşteriyi elde tutma maliyetine oranla 6 kat daha fazladır (Lin ve Wang, 2006: 272; Atalık, 2005: 2). Tüm bu durumlar göz önünde bulundurulduğunda, işletmeler açısından müşteri sadakati kavramı daha da önem kazanmaktadır. 
Geleneksel pazarlama ortamında müşteri sadakati; müşterilerin her türlü olumlu ya da olumsuz duruma rağmen, aynı işletmenin ürün ya da hizmetlerini tekrar satın almak suretiyle, onun müşterisi olmaya kendilerini adamasıdır (Oliver, 1999: 34). Müşteri sadakatine yönelik bir başka tanım ise, müşterilerin bir marka ile ilişkisini devam ettirmek istemesidir (Cyr vd., 2007: 45).

E-ticaretin gelişimi ile birlikte, sanal ortamlarda faaliyet gösteren işletme ve bu ortamlardan alışveriş yapan müşteri sayısında büyük artışlar gözlemlenmiştir. Dolayısıyla geleneksel ortamlarda gerçekleşen iş modelleri, elektronik ortamlara taşınmıştır. Geleneksel iş modelleri ile elektronik iş modellerini kıyasladığında elektronik iş sektöre; daha fazla esneklik, pazarda daha fazla sosyal yardım, daha düşük maliyet, daha hızlı işlem yeteneği, daha fazla ürün ya da hizmet seçeneği, daha fazla kolaylık ve daha çok kişiselleştirilmiş ürün ya da hizmet olanağı sunabilmektedir (Eng ve Kim, 2006: 439). E-iş uygulamalarının bu denli fırsatlar sunması ve işletmelerin daha fazla bu ortamda yer alması, sanal ortamlarda müşteri sadakatinin diğer bir ifadeyle elektronik müşteri sadakatinin (e-sadakat) sağlanması gereğini daha da önemli kılmıştır (Gommans vd., 2001: 43; Eng ve Kim, 2006: 439).

E-sadakat çok farklı şekillerde ve tanımlarda kullanılabilmektedir (Krumay ve Brandtweiner, 2010: 348). Örneğin Gommans vd. (2001: 44)'ne göre e-sadakat, geleneksel müşteri sadakatinin online müşteri davranışlarıyla sanal ortama taşınmasıdır. Eng ve Kim (2006: 439) ise e-sadakati; basit olarak sanal ortamdaki müşteri sadakati olarak tanımlamaktadır. E-sadakata yönelik bir başka tanım ise; müşterilerin daha önce alışveriş deneyiminde bulunduğu işletme internet sitesini, gelecekte tekrar ziyaret etmesi veya tekrar ürün ya da hizmet satın almasıdır (Heller ve Engelke, 2010: 30). E-sadakat bir başka tanımda, müşterilerin tekrar satın alma davranışları ile sonuçlanan elektronik işlemlere karşı olumlu tutumları şeklinde ifade edilmiştir (Anderson ve Srinivasan, 2003: 125; Srinivasan vd., 2002: 42). Jin vd. (2008: 327)'ne göre ise e-sadakat, müşterilerin ürün ya da hizmetlere karşı hem davranışsal hem de tutumsal olumlu davranışlarla tekrar satın alma davranışlarıdır. E-sadakatte, müşterilerin işletme internet sitelerine sıklıkla ziyaret etmesi ve bu sitelerde vakit geçirmeleri, ancak bu ziyaretler esnasında herhangi bir mal veya hizmet alımı yapmaması, e-sadakatin olmayacağı anlamına gelmemektedir (Gommans vd., 2001: 46).

Geleneksel ortamlarda olduğu gibi, elektronik ortamlarda da yeni müşteri elde etme maliyeti oldukça yüksektir. Ayrıca e-ortamlarda, değişim maliyetlerinin düşük olabilme intimalinden dolayı kullanıcılar, başka internet sitelerine geçebilmektedir. Dolayısıyla eişletmeler için, e-sadakat oluşturmak ekonomik açıdan bir zorunluluk olduğu söylenebilmektedir (Balabanis vd., 2006, 214; Devaraj vd., 2003: 186). Bu kapsamda işletmeler ürün ya da hizmetlerinin fiyatlarını düşürme (Eng ve Kim, 2006: 439) ya da sanal pazarların ihtiyacını karşılayacak farklılaşma stratejileri uygulamak suretiyle, rekabetçi avantaj elde etme ve e-sadakati sağlamaya (Souitaris ve Balabanis, 2007: 244) çalışmaktadır.

Sosyal medya sitelerinde e-sadakat; işletmelerin sosyal medya sitelerindeki sayfalarına yönelik olarak, kullanıcı, takipçi ya da hayranların, bu sayfaları tekrarlı ve sürekli olarak ziyaret etme / kullanma (Nusair vd., 2013:15) ve diğer kullanıcılara tavsiye etme (CurrásPérez vd., 2013: 66) hususundaki olumlu tutumlardır. Bu ortamdaki sayfalara yönelik e- 
sadakatin sağlanması, diğer işletmeler için olduğu gibi havayolu işletmeleri için de önemli olup; sadık kullanıcı sayısı havayolu işletmelerinin sosyal medya sitelerindeki sayfalarının değerini belirleyen en önemli unsurlardan biri olarak kabul edilebilmektedir. Söz konusu sayfalara yönelik sadık kullanıcıların olmayışı, havayolu işletmelerinin sosyal platformlardaki sayfalarında teknik ya da yönetsel alanlarda bazı sorunların olduğunun kanıtı sayılabilmektedir (Choi ve Kim, 2004: 12).

\subsection{Sosyal Bulunuşluk}

Geleneksel yöntemlerle kıyaslandığında, kimi insanlar açısından e-ticaret faaliyetleri, duygudan yana eksik, yüz yüze iletişimden yoksun, insan sıcaklığı ve sosyallikten uzak olarak nitelendirilebilmektedir. Bu açıdan değerlendirildiğinde işletmeler, ya e-ticaret faaliyetlerini böyle değerlendiren müşterilerden e-sadakat eğilimi göstermelerini beklemeyecek ya da müşterileri ile etkileşim halinde oldukları kurumsal internet sitelerini sosyal bulunuşluk seviyesini yükseltme yolunu seçecektir.

Olpak ve Çakmak (2009: 143-144) sosyal bulunuşluk kavramını; kişilerarası ilişkilerde her bir kişinin algılanış derecesi ya da bireylerin sanal iletişim ortamını gerçek bir insanmış gibi algılanma biçimi olarak tanımlamaktadır. Bu kavrama yönelik bir diğer tanım ise; bilgisayar ortamlarında ortaya çıkan bireyler arası farkındalık derecesidir. Ya da iletişim sürecinde yer alan diğer katılımcıları hissetmektir. Başka bir tanıma göre ise, müşterilerin alışveriş deneyimi yaşadıkları veya bilgi aldıkları internet sitesi ara yüzünde, insan sıcaklığı ve sosyallik hissi algılamalarıdır (Coverdale, 2010: 54). Internet sitelerinde insanların bulunduğu ses ya da video, sosyal açıdan zengin içerik ve kişiselleştirilmiş yazı, kullanıcıların insan sıcaklığını ve insanla birebir ilişki içerisinde olduğunu algılamasına neden olabilecektir. Sosyal bulunuşluk, e-sadakat ile pozitif bir ilişki içerisindedir. Müşteriler, elektronik ortamlarda faaliyette bulunan işletmelerin sayfalarındaki sosyal bulunuşluk seviyesini ne kadar yüksek hissederse, bu sayfalara karşı o derece sadık olabilecektir (Cyr vd., 2007: 47; Coverdale, 2010: 56). Diğer bir deyişle; e-sadakatin oluşum ve başarısı, sanal ortamda müşteri - işletme arasındaki ilişkinin insani olma derecesine bağlı olabilmektedir (Lin vd., 2008: 5).

Sosyal paylaşım sitelerinin, gerek birey gerekse işletmelerce sıklıkla kullanılır hale gelmesiyle beraber, sosyal bulunuşluk kavramı bu ortama da taşınmış ve diğer sektörlerde olduğu gibi, havayolu işletmelerinin resmi sosyal paylaşım sayfaları için de önemli hale gelmiştir. Bu noktada özellikle sosyal medya sayfalarında oluşan sanal topluluklar öne çıkmaktadır. Söz konusu topluluklar kullanıcıların, hem diğer kullanıcılar hem de söz konusu havayolu işletmesi ile aralarında duygusal bir bağ kurulmasına yardımcı olabilmektedir. Ayrıca sanal topluluklar sayesinde kullanıcılar, havayolu işletmelerinin sosyal ağlardaki sayfalarına ve dolayısıyla havayolu işletmesine karşı aidiyet hissedebilecektir. Sanal topluluklar sayesinde sayfaların sosyal bulunuşluluğunun yükselmesi ve aidiyet duygusunun varlığı, kullanıcıların bu sayfaları daha sık ve düzenli ziyaret etmesine ve dolayısıyla e-sadakatin artmasına olanak tanıyabilecektir (CurrásPérez vd., 2013: 63; Chung ve Buhalis; 2008: 73; Damásio vd., 2012: 129; Cao vd., 2013: 181). Havayolu işletmelerinin sosyal medya sitelerindeki sayfalarında sosyal bulunuşluk seviyesinin düşük olması, bu sayfaların kullanıcılarına sağlayabileceği değeri kısıtlayabilmektedir (Shipps ve Phillips, 2013: 38). 


\subsection{Etkileşim}

Genel olarak müşteri etkileşimi, işletme internet sitelerinde, işletmelerle müşteriler arasında karşılıklı iletişim olarak tanımlanmaktadır. E-sadakati etkileyen (Akar, 2004: 96) bir faktör olarak etkileşim; e-işletmelerin sayfalarında müşteri destek araçlarının varlığı ve etkinliği ile işletmelerle müşteriler arasındaki çift yönlü iletişimi kolaylaştırma derecesi olarak tanımlanabilmektedir. Etkileşim, müşterilerin ürün ve hizmetleri arama süreçlerini kısaltmak suretiyle, işletme ve işletmelerin internet sitesinin, müşterilerin belleklerinde yer almalarına ve müşterilerin algılanan değerini arttırmasına yardımcı olabilmektedir. Ayrıca etkileşim, e-işletmelerin müşterilere sundukları bilginin miktarını da arttırabilmektedir (Gommans vd., 2001: 45-46). Dolayısıyla işletmeler sanal ortamlarda yer alan kurumsal sayfalarına yönelik e-sadakati oluşturabilmek adına, 7 gün 24 saat erişime açık olmak durumundadır (Akar, 2004: 92). Chang ve Chen (2008: 2930)'e göre, internet üzerinden alışveriş yapmak için bilgi toplayan müşteriler, işletme internet sitelerindeki etkileşimden etkilenmektedir.

Illetişim ve etkileşim eksikliği, birçok işletmenin kurumsal internet sitesinin en büyük problemlerinden birini oluşturmaktadır. Bu problemler genel olarak; işletmelerin internet sitelerinde kendilerine yöneltilen soruları geç yanıtlamasından ya da ürün/hizmetlerle ilgili yetersiz ve /veya yanlış bilgi sunmasından kaynaklanabilmektedir (Srinivasan vd., 2002: 4243). E-sadakatin oluşumunu olumsuz yönde etkileyebilecek iletişim ve etkileşim eksikliğini ortadan kaldırabilmek adına; işletmeler e-posta ile müşterilerden gelen soru, sorun ve şikayetlere hızlı cevap verebilmeli, iyi organize edilmiş online yardım hattı kurulabilmeli ve sorgulama mekanizmaları oluşturma konusuna gereken önemi vermelidir (Aksoy, 2006: 57).

Diğer sektörlerde olduğu gibi, havayolu işletmeleri açısından da, sanal ortamlardaki sayfasında etkileşimin sağlanabilmesi önemlidir. Çünkü günümüz şartlarında, yolcuların tercih edebilecekleri havayolu işletmesi sayısı fazladır. Dolayısıyla müşteriler güçlenmiş ve istek, ihtiyaç ve/veya şikayetleri ile anında ilgilenilmesini talep eder hale gelmiştir (Asim ve Hashmi, 2005: 38). Bu kapsamda havayolu işletmelerinin sosyal medya sitelerindeki sayfalarında; özellikle genç ve aktif hedef kitlesini etkilemeleri, farklı ilgi alanlarından kişileri, farklı seçenek, uygulama ve araçla bir araya getirerek, hem işletme hem de kullanıcılar arası etkileşime girmelerini sağlayacak ortamı hazırlamaları, e-sadakatin oluşumunda büyük paya sahip olabilecektir (İşler ve Andiç, 2011). Çünkü sosyal medya sitelerindeki sayfalar aracılığı ile kullanıcılar, tanıdıkları ve/veya söz konusu sosyal medya sitelerinde sayfaları bulunan işletmeler ile etkileşimde bulunabilmek adına bu siteleri kullanmak niyetinde olabilmektedir (Alikılıç vd., 2013: 40). Örneğin Türk Hava Yolları (THY), THY olarak sosyal medya yönetimleriyle ilgili anahtar kelimelerinin etkileşim olduğunu dile getirmiş; sosyal medya sitelerinin sağlamış olduğu etkileşim sayesinde, yolculardan gelen yorum ve eleştirileri hizmet süreçlerine adapte etmeyi ve böylece THY ile müşteriler arasındaki bağı güçlendirmeyi hedeflediklerini beyan etmiştir (THY Sosyal medya, 2012). Ancak havayolu işletmelerinin sosyal medya sitelerinde başarılı bir etkileşim ortamı oluşturabilmeleri; kullanıcıların havayolu işletmeleriyle istedikleri zaman diliminde onlara ulaşabilmelerine bağlı olmaktadır. Bu bağlamda, Twitter'ı başarılı bir şekilde kullanan British Airlines, Virgin Atlantic, Quantas, American Airlines, BMI, KLM, United Airlines, CathayPasific ve Southwest havayollarının dahil edildiği bir araştırmada, yalnızca 
Southwest ile CathayPasific havayollarının, 24 saat esasına göre, sosyal medya sitelerinde kullanıcılarıyla etkileşimde bulunmaları için eleman çalıştırdığı sonucuna ulaşılmıştır (http://www.havayolu101.com/2012/05/25/twitter-ve-havayolu-sirketleri-2/).

Pietro vd. (2012: 69)'ne göre; havayolu işletmeleri gibi seyahat işletmelerinin sosyal medya sitelerindeki sayfalarında kullanıcıların keyif alabilecekleri, hem işletme hem de diğer kullanıcılar ile etkileşim halinde olabilecekleri, deneyimlerini paylaşabilecekleri ortamları sağlayabilmeleri, kullanıcıların bu sayfaları kullanım tutum ve niyetleri üzerinde etkili olabilmektedir. Kullanıcıların, havayolu işletmelerinin sosyal medya sitelerindeki sayfalarında, algıladıkları etkileşimin yüksek olması, aidiyet duygusunu ve dolayısıyla esadakati arttırabilmektedir (Damásio vd. 2012: 141). Hacıefendioğlu (2010: 66)'na göre de; işletmelerin sosyal medya sitelerindeki sayfalarında kullanıcıları ile etkileşime girebilmeleri, e-sadakati sağlayan unsurlardan biridir. Choi ve Kim (2004: 11)'e göre de; sanal ortamlarda e-sadakatin oluşumu için en iyi deneyimin sağlanması gerekmektedir. Kullanıcıların havayolu işletmelerinin sosyal medya sitelerindeki sayfalarından en iyi deneyimi elde edebilmeleri de; hem bu sayfalar aracılığı ile söz konusu havayolu işletmesi hem de bu sayfaların diğer kullanıcıları ile etkileşimine bağlı olabilmektedir.

\subsection{Değişim Maliyeti}

Değişim maliyeti, müşterilerin bir üreticinin ürün ya da hizmetlerini, diğer üreticinin ürün ya da hizmetini kullanmak için terk etmesi durumunda katlandığı maliyet olarak tanımlanmaktadır. Katlanılan bu maliyet para, zaman ve çaba olarak karşımıza çıkabilmektedir (Chang ve Chen, 2008: 2932). Bu noktadan hareketle, değişim maliyetinin doğası yalnızca ekonomik olmakla kalmayıp, aynı zamanda psikolojik ve duygusal bir yapı da sergilemektedir (Sharma ve Patterson, 2000: 474).

E-ticaret faaliyetlerinde, e-sadakat eğilimi gösterecek müşterileri oluşturmak oldukça güçtür. Çünkü Lin vd. (2008: 1)’ne göre; sanal ortamlarda, müşterilerin katlanacakları değişim maliyeti yok denecek kadar azdır. Dolayısıyla, e-sadakati yüksek seviyelere çıkarmak isteyen işletmeler, kendilerine rekabetçi avantaj sağlayacak ve değişim maliyetini arttıracak sistemler geliştirmesi faydalarına olabilecektir. İşletme internet sitelerinin değişim maliyetleri ne kadar yüksek olursa, müşterilerin e-sadakat seviyeleri de o derece yüksek olabilecektir (Chang ve Chen, 2008: 2932; Aydın vd., 2007: 222). Chang ve Chen (2008: 2927)'in araştırmalarına göre, sanal ortamlarda yaşanan etkileşim, söz konusu işletme sayfalarının değişim maliyetini doğrudan ve olumlu yönde etkilemekte ve dolayısıyla bu sayfalara yönelik kullanıcı sadakati de artmaktadır.

Havayolu işletmeleri, müşteri sadakatini sağlayıp, arttırabilmek ve sadakatin getirdiği avantajlardan istifade edebilmek amacıyla, 1980-1990'lı yıllarda, Sık Uçan Yolcu Programı (FFP) adı verilen sadakat programını geliştirmiştir. Bu program, havayolu işletmelerinin geleneksel pazarlama ortamında değişim maliyetini attıran unsurlardan biri olarak kabul edilmektedir (Chang ve Chen, 2007: 105).

Sosyal medya sitelerinin ve bu sitelerin kullanıcı sayılarının büyük oranda artması, havayolu işletmelerinin de bu sitelerde aktif olarak yer almasına zemin hazırlamış ve bu platformdaki rekabet artmıştır. Dolayısıyla havayolu işletmeleri, sosyal paylaşım sitelerindeki sayfalarında yer alan kullanıcılarını elde tutma aşamasında bazı sorunlarla karşılaşabilmektedir. Çünkü kullanıcıların diğer havayolu işletmelerinin sayfalarına geçişleri 
kolay olabilmektedir (Hacıefendioğlu, 2010: 66). Kullanıcıların sosyal medya sitelerinde sayfaları bulunan havayolu işletmeleri ile ilişkilerine ve dolayısıyla bu sayfaları kullanmaya devam etmeleri; kullanıcıların havayolu işletmelerinin sosyal medya sitelerindeki sayfalarının kendilerine sağladığı fayda ve promosyonu fark etmelerine bağlı olabilmektedir. Bu durumu fark eden kullanıcı, havayolu işletmesi ile ekonomik ilişkisini devam ettirmek isteyecek, diğer bir ifadeyle oluşabilecek maliyetlere katlanmamak adına başka bir havayolu işletmesi ile ilişki içerisinde olmak istemeyebilecektir (ilban ve Kaşlı, 2013: 137 - 138). Kullanıcıların sosyal medya sitelerindeki sayfalara yönelik duygusal olarak sadık olması, bireylerin söz konusu sayfalara yönelik yüksek aidiyet duygusu beslemelerine ve dolayısıyla başka bir havayolu işletmesinin sayfasını tercih etmemesine yardımcı olabilecektir (Cao vd., 2013: 181).

\section{5. Üye Profili}

İşletmelerin kurumsal internet siteleri içerisinde ya da son yıllarda gelişen sosyal medya siteleri aracılı̆̆ı ile sanal topluluklar kurulabilmektedir. Bu sanal topluluklar, işletme tarafından kurulabileceği gibi, müşteriler tarafından da oluşturulabilmektedir. Tanım olarak sanal topluluklar; bünyesinde mevcut ve potansiyel müşterileri bir arada tutmak ve işletmelerce sunulan ürün ya da hizmetlerle ilgili bilgi ve fikir paylaşımını kolaylaştırmak adına e-işletmelerce ya da insanlar tarafından kurulmuş sanal bir varlıktır. Sanal topluluklar, günümüz teknoloji çağında oldukça önemli bir gelişme olarak kabul edilebilmektedir. Sanal topluluklarda, hakkında konuşulan ürün ya da hizmetlerle ilgili bilgi ve fikirler insanlar arasında paylaşılabilmektedir. Dolayısıyla bu durum, mevcut ya da potansiyel müşterilerin, o ürün ya da hizmete karşı olan tutumlarını olumlu veya olumsuz yönde etkileyerek, müşteri sadakatinin oluşmasına ya da ortadan kalkmasına neden olabilecektir (Srinivasan vd., 2002: 43-44; Smith, 2000: 31-34). Kullanıcılar da bir işletmenin sosyal ağ sitelerindeki sayfalarını ziyaret etmek ve kullanmak için, sanal topluluk üyelerinin profillerini dikkate alabilmektedir. Hacıefendioğlu (2010: 60); sosyal paylaşım sitelerinde üye bağlılığı üzerine bir araştırma yapmış ve araştırma neticesinde, üye profilinin, üye bağlılığını olumlu yönde etkilediği sonucuna ulaşmıştır.

Havayolu işletmeleri hem kurumsal internet sayfalarında hem de sosyal medya sitelerindeki sayfalarında; bu sayfa üyeleri ile birlikte sanal topluluklar oluşturabilmektedir (Asim ve Hashmi, 2005: 37). Chung ve Buhalis (2008: 70), bireylerin sanal topluklara üye olmasının; bilgi edinme, sosyo-psikolojik ve hazsal anlamda faydalar elde etmesini ve bu faydaların, sanal topluluklara karşı tutumu olumlu yönde etkilediğini dile getirmiştir. Özellikle hizmet sektöründe yer alan havayolu hizmetlerinin soyutluk özelliğinden (Özer ve Gülpınar, 2005: 50) dolayı, henüz seyahat planı yapan bireyler, sanal toplulukları ziyaret edebilmekte ve bu belirsizlikten kaynaklanan riskleri ortadan kaldırabilmektedir (Chung ve Buhalis, 2008: 71-72; Maurer ve Wiegmam, 2011: 488). Ayrıca, havayolu işletmelerinin sosyal medya sitelerindeki sayfalarda oluşturdukları sanal topluluk sayesinde üye yolcular, söz konusu havayolu işletmesi ile ilgili seyahat deneyimlerini diğer üyelerle paylaşabilmekte ve bu sayede kişilerin satın alma kararlarını olumlu / olumsuz yönde etkileyebilmektedir. Bu durum kullanıcıların e-memnuniyet seviyesini artırmakta olup bu durum, kullanıcıların havayolu işletmelerinin sosyal paylaşım sitelerindeki sayfalarına yönelik tekrarlı kullanım / ziyaret niyetini de pozitif yönde geliştirebilmektedir (Pulvirenti 
ve Jung, 2011: 515; Nusair vd., 2013: 20; Maurer ve Wiegmam, 2011: 493; Sledgianowski ve Kulviwat, 2009: 74).

\subsection{Aidiyet Duygusu}

Tanım olarak aidiyet duygusu, müşterilerin dijital ortamda faaliyet gösteren işletmelerin ürün ya da hizmetlerinden yine internet aracılığıyla faydalanması neticesinde, kendisini eişletmenin ayrılmaz bir parçası olarak görmesidir (Al-Agaga ve Nor, 2011: 299).

E-işletmeler, kurumsal sayfalarına yönelik aidiyet duygusunu oluşturabilmek için öncelikle, müşteri-işletme-çalışan arasında açık bir iletişim ortamı kurmalı, karşılıklı saygı ortamını oluşturmalı ve müşteriyle çalışanlarına gereken önemi vermelidir (Çırpan, 2011). İşletmelerin özellikle, müşterilerine duygusal faydalar sağlayacak ve onların duygularına hitap edecek davranışlarda bulunması, kampanya, indirim, promosyon bilgilerini müşterilere duyurabilmesi, müşterilerin istek, ihtiyaç ve şikayetlerini doğrudan ve zahmetsizce işletmeye ulaşmalarını sağlayacak ortamı ve ödül programları geliştirmesi (http://www.kariyer.net/kariyerrehberi/kariyerRehberiDetay.kariyer?kn=611) ya da karşıtlık duygusunu oluşturabilmesi (http://www.mienotes.com/2009/10/adalet-aidiyetve-sadakat/) müşterilerin işletmeye olan aidiyet duygusunu arttırmaya olanak sağlayabilecek bir diğer unsurdur. Örneğin, bayrak taşıyıcı olan THY'den başka bir havayolunu tercih etmeyecek olan müşteriler, diğer havayolu işletmelerine karşıttır. Dolayısıyla bu yolcular, THY'ye karşı güçlü bir aidiyet duygusuyla birlikte güçlü bir sadakat duygusunu da beslemektedir. Özellikle elektronik ortamın verdiği sanallık duygusunu aşabilmek adına, bu kavramların işletme içerisine adapte edilmesi, müşterilerin işletme internet sitelerine karşı yüksek derecede e-sadakat beslemelerine yardımcı olabilecektir. Al-Agaga ve Nor (2012: 297); aidiyet duygusunun, müşterilerin tekrarlı satın alma niyetini olumlu yönde etkilediği ve dolayısıyla, güçlü aidiyet duygusunun güçlü e-sadakat yarattığı sonucuna ulaşmıştır. Ayrıca işletmeler gerek internet gerekse sosyal medya sitelerindeki sayfalarında aidiyet duygusu oluşturmaları durumunda, müşterileri ile uzun vadeli ilişkiler kurabilecek, işletmelerin söz konusu sayfalarına kendini ait hisseden müşteriler bu işletmenin gönüllü marka elçisi olarak, olumlu ağızdan ağıza iletişimi sağlayarak, işletmeye yeni müşteriler kazandırabilecek (Hamid ve McGrath, 2005: 37; Çiftçi ve Koçak, 2009: 107) ve sürdürülebilir karlılık avantajı (Barutçugil, 2010) elde edebilecektir.

Müşterilerin özellikle sosyal medya siteleri ve burada faaliyette bulunan işletmelerle iletişime geçmek için, aidiyet duygusu ihtiyaçlarının karşılanması gerekmektedir (Ünlü, 2010; Lin, 2008: 523; Currás-Pérez vd., 2013: 63). Sosyal medya sitelerinde aidiyet duygusu; bu sitelerde oluşturulan sayfalardaki sanal topluluklarla yakın ilişki içerisindedir. Kullanıcıların söz konusu sayfalarda oluşmuş grup ya da sanal toplulukları değerli bir grup olarak görmesi, söz konusu topluluğa ait olmaktan gurur duymaları, aidiyet duygusu olarak tanımlanabilmektedir (Damásio vd., 2012: 128). Damásio vd. (2012: 127) ve Cao vd. (2013: 175)'ne göre; sosyal medya sitelerindeki sayfalarına yönelik aidiyet duygusu yükseldikçe, söz konusu sayfalara yönelik olumlu tutumlar ve sürekli kullanım niyet ve eylemleri artabilecektir. Dolayısıyla havayolu işletmelerinin sosyal medya sitelerindeki sayfalarında aidiyet duygusunu oluşturulması durumunda; kullanıcılar, hem havayolu işletmesi hem de diğer kullanıcılar ile duygusal bağlar kurabilecek ve söz konusu sayfalara yönelik sadakat duygusu artabilecektir (Cao vd., 2013: 175; Maurer ve Wiegmam, 2011: 487). Kullanıcıların diğer işletme sayfalarında olduğu gibi, havayolu işletmelerinin de sosyal 
paylaşım sitelerindeki sayfalarında; içerik oluşturmaları, var olan bir içeriğe katkıda bulunmaları ve sanal topluluklara dahil olmasının teşviki, kullanıcıların havayolu işletmelerinin sosyal ağlardaki sayfasına yönelik aidiyet duygusunun gelişebilmesine yardımcı olabilecektir (Nusair vd., 2013: 20; Chung ve Buhalis, 2008: 73; Damásio vd., 2012: 129; Currás-Pérez vd., 2013: 63).

\section{YÖNTEM}

Bu bölümde araştırma kapsamında anket soruları, verilerin toplanması, verilerin analizi ve analiz sonuçları ile ilgili bilgiler yer almaktadır.

\subsection{Anket Soruları}

Araştırmaya yönelik anket çalışması, 2 bölümden oluşmaktadır. Illk bölümde, kullanıcıların sosyal medya sitelerinde yer alan havayolu işletmelerinin sayfalarına yönelik e-sadakat ve e-sadakati etkilediği düşünülen; sosyal bulunuşluk, etkileşim, değişim maliyeti, üye profili ve aidiyet duygusuna yönelik sorular yer almaktadır. Değişkenlere yönelik sorular, esadakat için Anderson ve Srinivasan (2003), sosyal bulunuşluluk için Cyr vd. (2007), etkileşim için Ballantine (2005) ile J. Wu ve Chang (2005), değişim maliyeti için Sharma ve Patterson (2000), üye profili için Hacıefendioğlu (2010) ve aidiyet duygusu için Guo ve Liu (2010)'nun çalışmalarından yararlanarak oluşturulmuş ve havayolu taşımacılığı sektörüne adapte edilmiştir. Değişkenlere yönelik sorular, (1) Kesinlikle katılmıyorum ..... (5) Kesinlikle katılıyorum şeklinde 5'li Likert ölçeğiyle hazırlanmıştır. İkinci bölümde ise, katılımcıların demografik özellikleri ile internet ve sosyal medya kullanım bilgilerini içeren; yaş, cinsiyet, medeni durum, eğitim durumu, aylık ortalama gelir, internet kullanım yılı, internet kullanım sıklığı, hangi sosyal paylaşım sitesine üye oldukları, hangi havayolu işletmesini ve/veya işletmelerini takip ettikleri ve havayolu işletmelerinin oluşturdukları içerikleri hangi sıklıkta takip ettikleri gibi sorular yer almaktadır.

\subsection{Verilerin Toplanması}

Araştırma kapsamında, Türkiye'de faaliyet gösteren havayolu işletmelerinin, sosyal paylaşım siteleri olan Facebook ve Twitter'daki sayfalarını takip eden 490 kişiye, internet ortamında uygulanmıştır.

\subsection{Verilerin Analizi}

Verilerin analizi amacıyla; öncelikle araştırmada kullanılacak test yöntemlerini belirlemek adına, çalışmaya ait verilerin normal dağılıma sahip ve grup varyanslarının eşit olup olmadığı test edilmiştir. Bu amaçla, araştırmayı oluşturan her bir değişkenin normal dağılıma uygunluğu Tek Örneklem Kolmogorov-Smirnov testi kullanılarak incelenmiş, ancak (p) anlamlılık düzeyinin 0.05 'ten küçük olması nedeniyle, parametrik olmayan testlerden Mann-Whitney U, Kruskal Vallis ve Korelasyon Analizi yöntemleri kullanılmıştır. Demografik verilerin analizinde frekans tabloları oluşturulmuştur. Sosyal medya sitelerinde yer alan havayolu işletmelerinin sayfalarına yönelik e-sadakat ve e-sadakati etkileyen değişkenlere ilişkin sorulara güvenilirlik analizi yapılmıştır. Analiz sonucunda değişkenlere ait Cronbach Alfa Katsayıları tablo 1'deki gibidir. 
Tablo 1: Değişkenlere Yönelik Güvenirlik Analizi Sonuçları

\begin{tabular}{l|c}
\hline Ankete dahil edilen değişkenler & Güvenirlik katsayısı \\
\hline Sosyal bulunuşluk & 0.961 \\
\hline Etkileşim & 0.975 \\
\hline Değişim maliyeti & 0.944 \\
\hline Üye profili & 0.732 \\
\hline Aidiyet duygusu & 0.967 \\
\hline E-sadakat & 0.972 \\
\hline
\end{tabular}

Ankete dahil edilen değişkenlerin güvenirlik katsayıları incelendiğinde, tüm değişkenlerin cronbach alfa değerinin, 0.70 'in üzerinde olması nedeniyle, değişkenler güvenirlik testinden geçmişlerdir (Büyüköztürk, 2010: 171).

\subsection{Analiz Sonuçları}

Anket katılımcılarına yönelik demografik bilgiler incelendiğinde, cevaplayıcıların \% 50,6'sı kadın, \% 49,4'ü erkek, bekar ve evli oranı neredeyse yarıya, büyük bir çoğunluğu $(\% 61,8)$ 20-29 yaş aralığında, üniversite düzeyi eğitim seviyesine $(\% 49,2)$ sahip olup, ortalama aylık gelirleri en fazla (\% 48) 1000 - 2000 TL arasındadır. Soruları cevaplayan katılımcıların \% 66,5'i 7 yıldan fazla süredir ve her gün (\% 90'dan fazla) internet kullanmaktadır. Araştırmaya dahil olan örneklem grubu, en fazla Facebook ve Twitter'i kullanmakta olup, bu paylaşım sitelerinde takip edilen havayolu işletmesi oranları; 47 'sinin $(\% 9,6)$ THY, 90 'ının (\% 18,4) Pegasus, 25'inin (\% 5,1) Sunexpress, 152'sinin (\% 31,0) Onurair, 58'inin (\% 11,8 ) Atlasjet, 118 'inin (\% 24,1) Anadolujet olduğu saptanmıştır. Kullanıcılar takip ettikleri söz konusu havayolu işletmelerini hemen her gün takip ettikleri $(\% 72,8)$ belirlenmiştir.

Sosyal paylaşım sitelerinde sayfaları bulunan havayolu işletmelerinin takipçilerinin esadakat ve e-sadakati etkilediği düşünülen; sosyal bulunuşluk, etkileşim, değişim maliyeti, üye profili ve aidiyet duygusuna yönelik düzeyler, tanımlayıcı istatistikler yardımı ile incelenmiş ve çıkan sonuçlar tablo 2'de sunulmuştur.

Tablo 2: Kullanıcıların Sosyal Medya Sitelerinde Yer Alan Havayolu İşletmelerinin Sayfalarına Yönelik E-sadakat ve E-Sadakati Etkileyen Değişkenlere Yönelik Düzeylerinin Değerlendirilmesi

\begin{tabular}{lllll}
\hline & Minimum & Maksimum & Ortalama & Std. Sapma \\
\hline E-sadakat & 1,000 & 5,000 & 4,035 & 0,994 \\
\hline Sosyal bulunuşluk & 1,000 & 5,000 & 3,687 & 1,001 \\
\hline Etkileşim & 1,000 & 5,000 & 3,733 & 1,308 \\
\hline Değişim maliyeti & 1,000 & 5,000 & 3,815 & 0,975 \\
\hline Üye profili & 1,000 & 5,000 & 3,372 & 1,051 \\
\hline Aidiyet duygusu & 1,000 & 5,000 & 3,787 & 0,981 \\
\hline
\end{tabular}

Ankete katılan kişilerin havayolu işletmelerinin sosyal paylaşım sitelerindeki sayfalarına yönelik e-sadakat ve e-sadakati etkileyen değişkenlere verilen puanlar dikkate alındığında, üye profili değişkeni hariç, diğer tüm değişkenlere " 4 " katılıyorum ifadesine yakın olduğu 
görülmüştür. Bu noktadan hareketle, ankete katılan kullanıcıların, havayolu işletmelerinin sosyal paylaşım sitelerindeki sayfalarına sadık, söz konusu sayfalarda insan sıcaklığı ve karşılıklı etkileşime sahip olarak gördüğü söylenebilir. Ayrıca yine ankete katılan kullanıcıların, havayolu işletmelerinin sosyal paylaşım sitelerindeki sayfalarına yönelik aidiyet duygularının yüksek ve başka bir havayolu işletmesini takip etmeleri durumunda, katlanacağı değişim maliyetinin fazla olacağı tespit edilmiştir. Havayolu işletmelerinin sosyal platformlardaki sayfalarına yönelik e-sadakati etkilediği düşünülen "üye profili" değişkenine yönelik ortalama "3" kararsızım seviyesinde olduğu görülmektedir. Dolayısıyla, mevcut ve potansiyel kullanıcıların, havayolu işletmelerinin sosyal paylaşım sitelerindeki sayfalarına yönelik e-sadakatin oluşabilmesi için, üye profilinin çok da önemli olmadığı dile getirilebilir.

Bağımlı değişken e-sadakat ile bağımsız değişkenler olan; sosyal bulunuşluk, etkileşim, değişim maliyeti, üye profili ve aidiyet duygusu arasındaki ilişkinin ölçülmesi amacıyla korelasyon analizi uygulanmıştır. Ancak değişkenlerin sürekli bir dağılıma sahip olmaması nedeniyle, parametrik olmayan korelasyon analizinden, Spearman Brown Sıra Farkları korelasyon katsayısı kullanılmış olup, analiz sonuçları tablo 3'de gösterilmiştir.

Tablo 3: E-sadakat ile E-sadakati Etkileyen Değişkenler Arasındaki iliş̧ilerin Korelasyon Analizi

\begin{tabular}{lccc}
\hline Bağımsız Değişkenler & Bağımlı Değişken & Spearman's rho & $p$ \\
\hline Sosyal bulunuşluk & E-sadakat & 0.660 & 0.000 \\
\hline Etkileşim & E-sadakat & 0.525 & 0.000 \\
\hline Değişim maliyeti & E-sadakat & 0.701 & 0.000 \\
\hline Üye profili & E-sadakat & 0.452 & 0.000 \\
\hline Aidiyet duygusu & E-sadakat & 0.692 & 0.000 \\
\hline
\end{tabular}

Sosyal medya sitelerinde sayfaları bulunan havayolu işletmelerini takip etmeyi bırakma neticesinde karşı karşıya kalınacak maliyet ile e-sadakat arasında, yapılan korelasyon analizi sonucunda, pozitif, yüksek düzeyde ve anlamlı bir ilişki bulunmuştur ( $r h o=0.701$, $\mathrm{p}<0.05)$. Diğer bir ifadeyle, havayolu işletmelerinin sosyal medya sitelerindeki sayfalarına yönelik değişim maliyeti yükseldikçe e-sadakat da artabilecek olup, e-sadakatin toplam varyansının \%49'unun değişim maliyeti tarafından açıklandığı tespit edilmiştir. Havayolu işletmelerinin sosyal medya sitelerindeki sayfalarına yönelik e-sadakattaki değişimi en fazla açıklayan ikinci değişken aidiyet duygusudur $\left(r^{2}=\% 48\right)$. Buna göre, aidiyet duygusu ile e-sadakat arasında pozitif, yüksek düzeyde ve anlamlı bir ilişkinin mevcut olduğu söylenebilir (rho=0.692, p<0.05). Başka bir şekilde ifade etmek gerekirse, havayolu işletmelerinin Facebook, Twitter gibi sosyal paylaşım sitelerindeki sayfalarına yönelik takipçilerin aidiyet duygusu arttıkça, e-sadakat seviyesinin de artacağı dile getirilebilir. Bu çalışmada e-sadakati en fazla açıklayan ve araların pozitif, anlamlı ve yüksek düzeyde ilişki tespit edilen üçüncü değişken ise, sosyal bulunuşluktur ( $r h o=0.660, p<0.05, r^{2}=\% 44$ ). Onu; etkileşim (rho=0.525, p<0.05, \%28) ve üye profili (rho=0.452, p<0.05, \%20) takip etmektedir.

Araştırma kapsamında ayrıca; e-sadakatin, yaş, cinsiyet, medeni durum, eğitim durumu, aylık ortalama gelir, internet kullanım yılı, internet kullanım sıklığı, hangi sosyal paylaşım sitesine üye oldukları, hangi havayolu işletmesini ve/veya işletmelerini takip ettikleri ve 
havayolu işletmelerinin oluşturdukları içerikleri hangi sıklıkta takip ettikleri sorularının oluşturduğu demografik değişkenlere göre anlamlı bir farklılık gösterip göstermediği test edilmiştir. Araştırmaya katılan bireylerin cinsiyet ve medeni durumları ile e-sadakat arasında anlamlı bir fark olup olmadığı, Mann Whitney U-Testi ile analiz edilmiştir. Analiz sonuçları tablo 4'te özetlenmiştir.

Tablo 4: Kullanıcıların Havayolu iş̧letmelerini Sosyal Paylaşım Sitelerinden Takip Etme Sonucundaki E-Sadakat Değişkeninin Cinsiyete ve Medeni Duruma Göre Farklılaşması

\begin{tabular}{|c|c|c|c|c|c|c|}
\hline & Cinsiyet & $\mathbf{n}$ & Sıra Ortalaması & Sıra Toplamı & $\mathbf{U}$ & $\mathbf{p}$ \\
\hline \multirow{2}{*}{ E-Sadakat } & Kadın & 236 & 232.11 & 54778.50 & \multirow{2}{*}{26812.50} & \multirow{2}{*}{.696} \\
\hline & Erkek & 232 & 236.93 & 54967.50 & & \\
\hline & Medeni Durum & $\mathbf{n}$ & Sıra Ortalaması & Sıra Toplamı & $\mathbf{U}$ & $\mathbf{p}$ \\
\hline \multirow{2}{*}{ E-Sadakat } & Bekar & 219 & 228.21 & 49977.50 & \multirow{2}{*}{25887.500} & \multirow{2}{*}{.664} \\
\hline & Evli & 242 & 233.53 & 56513.50 & & \\
\hline
\end{tabular}

Yapılan Mann Whitney U-testi uygulamalarına göre; e-sadakat ile cinsiyet $(U=26812.50$; $p=0.696>0.05)$ ve medeni durum $(U=25887.500 ; p=0.664>0.05)$ değişkenleri arasında anlamlı bir farklılık gözlenememiştir.

Sosyal paylaşım sitelerinde yer alan havayolu işletmelerinin sayfalarına yönelik e-sadakatin ölçülmesi adına yapılan anket çalışmasına katılan cevaplayıcıların, e-sadakatin, yaş değişkenine göre anlamlı bir farklılık gösterip göstermediğinin belirlemek amacıyla, parametrik olmayan testlerden Kruskal-Wallis $\mathrm{H}$-testi uygulanmıştır.

Tablo 5: Kullanıcıların Havayolu İşletmelerini Sosyal Paylaşım Sitelerinden Takip Etme Sonucundaki E-sadakatin Yaşa Göre Farklılaşması

\begin{tabular}{|c|c|c|c|c|c|c|c|}
\hline & Yaş & $\mathrm{n}$ & Sıra Ort. & sd & $x^{2}$ & p & Anlamlı Fark \\
\hline \multirow{3}{*}{ E-sadakat } & Genç yaş grubu (1) & 307 & 232.44 & \multirow{3}{*}{2} & \multirow{3}{*}{.215} & \multirow{3}{*}{.898} & \multirow{3}{*}{-} \\
\hline & Orta yaş grubu (2) & 151 & 228.92 & & & & \\
\hline & İleri yaş grubu (3) & 4 & 256.25 & & & & \\
\hline
\end{tabular}

Tablo 5'te de görüldüğü gibi; anket çalışmasının uygulanması esnasında, katılımcıların yaşları; "20 yaşından küçük, 20 - 29 yaş, 30 - 39 yaş, 40 - 49 yaş, 50 - 59 yaş, 60 yaş ve üzeri" şeklinde sorulmuştur. Ancak yapılan analizlerin daha anlaşılır sonuçlar verebilmesi adına, test uygulanmadan önce, katılımcıların yaşları; 29 yaş ve aşağısı olan katılımcılar genç, 30-49 yaş arası orta ve 50 yaş ve üzeri olanlar da ileri yaş grubu olarak yeniden kodlanmıştır ve Kruskal-Wallis $\mathrm{H}$ testi neticesinde, e-sadakat değişkeni ile yaş arasında anlamlı bir fark bulunamamıştır.

Havayolu işletmelerinin sosyal paylaşım sitelerindeki sayfalarını takip eden internet kullanıcılarına uygulanan anket çalışmasına göre, e-sadakat ile katılımcıların eğitim durumu ve ortalama aylık gelir değişkenleri arasında anlamlı bir farklılık olup olmadığı araştırılmıştır. Anketin yanıtlayıcılara sorulması esnasında, katılımcıların gelir grupları; 
"1000 TL'den az, 1000 - 2000 TL, 2001 - 3000 TL, 3001 - 4000 TL, 4001 TL ve üzeri" şeklinde sorulmuştur. Ancak, yapılan analiz neticesinde sonuçların daha anlaşılır olabilmesi adına, gelir grupları SPSS'te yeniden kodlanmıştır. Bu kapsamda, katılımcıların ortalama aylık gelirleri; 1000 TL'den az olanlar düşük, 1000 - 3000 TL orta ve son olarak 3001 TL ve üzeri ortalama aylık gelir yüksek gelir olmak üzere 3 gruba ayrılmıştır. Bu kapsamda değişkenlere, Kruskal Wallis testi uygulanmış ve anlamlı farkın nereden kaynaklandığını ortaya çıkarmak amacıyla, Mann Whitney U analizi yapılmıştır.

Tablo 6'dan da görüldüğü gibi, araştırmaya katılan sosyal paylaşım sitesi kullanıcılarının, esadakat puanları, eğitim durumu $\left(\chi^{2}=95.495, p=0.00<0.05\right)$ ve ortalama aylık düzeyi $\left(\chi^{2}=\right.$ $67.025, p<0.05)$ 'ne göre anlamlı bir farklılık göstermektedir. Grupların sıra ortalamaları dikkate alındığında, tüm alt gruplarda en yüksek sıra ortalaması, lisansüstü eğitime sahip (329.68) ve yüksek gelir grubunda (274.97) yer alan sosyal paylaşım sitesi kullanıcılarına ait olduğu saptanmıştır.

Tablo 6: Kullanıcıların Havayolu İşletmelerini Sosyal Paylaşım Sitelerinden Takip Etme Sonucundaki E-sadakatin Eğitim Durumu ve Ortalama Aylık Gelire Göre Farklılaşması

\begin{tabular}{|c|c|c|c|c|c|c|c|}
\hline & Eğitim Durumu & $\mathbf{n}$ & Sira Ort. & sd & $x^{2}$ & p & Anlamlı Fark \\
\hline \multirow{5}{*}{ E-sadakat } & İlköğretim (1) & 25 & 83.16 & \multirow{4}{*}{3} & \multirow{4}{*}{95.495} & \multirow{4}{*}{0.000} & \multirow{4}{*}{$\begin{array}{c}2-1,3-1,4-1,3-2 \\
4-2,4-3\end{array}$} \\
\hline & Lise (2) & 159 & 179.67 & & & & \\
\hline & Üniversite (3) & 231 & 262.68 & & & & \\
\hline & Lisansüstü (4) & 46 & 329.68 & & & & \\
\hline & Gelir Grubu & $\mathbf{N}$ & Sıra Ort. & sd & $x^{2}$ & p & Anlamlı Fark \\
\hline \multirow{3}{*}{ E-sadakat } & Düşük (1) & 80 & 121.49 & \multirow{3}{*}{2} & \multirow{3}{*}{67.025} & \multirow{3}{*}{0.000} & \multirow{3}{*}{$2-1,3-1$} \\
\hline & Orta (2) & 362 & 251.36 & & & & \\
\hline & Yüksek (3) & 16 & 274.97 & & & & \\
\hline
\end{tabular}

Eğitim durumu ile ilgili Mann Whitney $U$ sonucuna göre; lise, üniversite ve lisans üstü eğitime sahip takipçiler, ilköğretim mezunu takipçilere; üniversite mezunu katılımcılar, lise mezunu katılımcılara; lisansüstü katılımcılar ise üniversite mezunu katılımcılara kıyasla havayolu işletmelerinin sosyal paylaşım sitelerindeki sayfalarına yönelik e-sadakat puanlarının daha yüksek olduğu görülmüştür. Ortalama aylık gelir sonuçlarına göre ise; orta ve yüksek gelir düzeyi grubuna ait e-sadakat puanları, düşük gelir düzeyi grubuna kıyasla daha yüksek puana sahiptir.

Havayolu işletmelerinin sosyal paylaşım sitelerindeki sayfalarını takip eden internet kullanıcılarına uygulanan anket çalışmasına göre, e-sadakat değişkeninin, katılımcıların internet kullanım sürelerine ve sıklığına göre anlamlı bir farklılık gösterip göstermediği araştırılmıştır. Söz konusu farklılı̆̆ test edebilmek amacıyla, Kruskal-Wallis yöntemi uygulanmış ve analiz sonuçları tablo 7'de özetlenmiştir. 
Tablo 7: Kullanıcıların Havayolu iş̧letmelerini Sosyal Paylaşım Sitelerinden Takip Etme Sonucundaki E-sadakatin İnternet Kullanım Süresi ve Sıklığına Göre Farklılaşması

\begin{tabular}{|c|c|c|c|c|c|c|c|}
\hline & İnternet Kullanım Süresi & $\mathbf{N}$ & Sira Ort. & sd & $x^{2}$ & $\mathbf{p}$ & Anlamlı Fark \\
\hline & 3 yıldan az (1) & 78 & 164.19 & & & & \\
\hline \multirow[t]{4}{*}{ E-sadakat } & 4-9 yıl (2) & 239 & 219.48 & 2 & 43.309 & 0.000 & $2-1,3-1,3-2$ \\
\hline & 9 yıldan fazla (3) & 140 & 281.36 & & & & \\
\hline & Internet Kullanım Sıklığı & $\mathbf{N}$ & Sira Ort. & sd & $x^{2}$ & $\mathbf{p}$ & Anlamlı Fark \\
\hline & Her gün mutlaka (1) & 281 & 264.73 & & & & \\
\hline \multirow[t]{2}{*}{ E-sadakat } & Hemen hemen her gün (2) & 142 & 194.03 & 2 & 65.779 & 0.000 & $1-2,1-3,2-3$ \\
\hline & Haftada 1-2 kez (3) & 36 & 100.79 & & & & \\
\hline
\end{tabular}

Buna göre; e-sadakat ile internet kullanım süresi $\left(\chi^{2}=43.309 ; p<0,05\right)$ ve sıklığı $\left(\chi^{2}=65.779\right.$; $p<0,05)$ arasında istatistiki olarak anlamlı bir farklılık olduğu sonucuna ulaşılmıştır. Çalışmanın alt değişkenlerine yönelik en yüksek puan ortalamaları, internet kullanım süresi 9 yıldan fazla olan ve her gün mutlaka internet kullanan katılımcılarda olduğu gözlemlenmiştir. Araştırmanın alt boyutlarında gözlemlenen anlamlı farklılaşmanın kaynağını belirlemek amacıyla Mann Whitney U-testi uygulanmıştır. Katılımcıların internet kullanım sürelerine göre; 4 ile 9 yıldır internet kullanan anket yanıtlayıcılarının, 3 yıldan az süredir internet kullanan katılımcılara; 9 yıldan fazla süredir internet kullanan katılımcıların da hem 4-9 yıl hem de 3 yıldan az süredir internet kullanan katılımcılara kıyasla, daha yüksek e-sadakat puanlarına sahip olduğu ortaya çıkmıştır. Katılımcıların internet kullanım sıklıklarına yönelik anlamlı farklılığın kaynağını bulmak için yapılan Mann Whitney U-testi sonuçları doğrultusunda ise; etkileşim ve üye profili değişkenleri haricinde, diğer tüm değişkenlerde internet kullanım sıklığı arttıkça, değişkenlere yönelik puanların arttı̆̆ı gözlemlenmiştir.

Sosyal paylaşım sitelerinde yer alan havayolu işletmelerinin sayfalarına yönelik, e-sadakat seviyesinin, takip edilen havayolu işletmesine göre farklılık gösterip göstermediğini belirleyebilmek adına, parametrik olmayan testlerden Kruskall Wallis yöntemi uygulanmıştır.

Tablo 8: Kullanıcıların Havayolu İşletmelerini Sosyal Paylaşım Sitelerinden Takip Etme Sonucundaki E-sadakatin, Sosyal Medya Sitelerinden Takip Edilen Havayolu isşletmesine Göre Farklılaşması

\begin{tabular}{|c|c|c|c|c|c|c|c|}
\hline & Havayolu İşletmesi & $\mathbf{N}$ & Sira Ort. & sd & $\chi^{2}$ & p & $\begin{array}{c}\text { Anlamlı } \\
\text { Fark }\end{array}$ \\
\hline \multirow{6}{*}{ E-sadakat } & THY (1) & 35 & 201.54 & \multirow{6}{*}{5} & \multirow{6}{*}{12.855} & \multirow{6}{*}{0.025} & \multirow{6}{*}{$\begin{array}{l}6-1,6-2 \\
6-3,6-4\end{array}$} \\
\hline & Pegasus (2) & 83 & 216.86 & & & & \\
\hline & Sunexpress (3) & 24 & 199.69 & & & & \\
\hline & Onurair (4) & 151 & 228.22 & & & & \\
\hline & Atlasjet (5) & 57 & 244.89 & & & & \\
\hline & Anadolujet (6) & 118 & 266.79 & & & & \\
\hline
\end{tabular}


Tablo 8'den de görüleceği üzere, katılımcıların sosyal paylaşım sitelerinde takip ettikleri havayolu işletmesi ile e-sadakat arasında anlamlı bir farklılık vardır $\left(\chi^{2}=12.855, p<0.05\right)$. Havayolu işletmelerinin sıra ortalamaları dikkate alındığında, sosyal paylaşım sitelerinde faaliyet gösteren havayolu işletmeleri arasında en yüksek puanı olan işletme Anadolujet'tir (266.79). Tüm değişkenlerde, Anadolujet havayolu işletmesini, Atlasjet havayolu işletmesi takip etmiştir. Gruplar arasında gözlenen anlamlı farkın kaynağını belirlemek amacıyla, Mann Whitney U-testi uygulanmıştır. Buna göre; katılımcılar, Anadolujet havayollarının sosyal paylaşım sitelerindeki sayfalarını; THY, Pegasus, Sunexpress ve Onur havayollarının sayfalarına kıyasla, sadakat oluşturma özelliklerinin daha yüksek olduğunu dile getirmişlerdir.

Facebook, Twitter gibi popüler sosyal paylaşım sitelerinde yer alan havayolu işletmeleri ile bu kanallar aracılığıyla iletişim kuran anket yanıtlayıcılarının, sosyal paylaşım sitelerinde yer alan bu havayollarını takip etme sıklığı (çok sık: her gün mutlaka; oldukça sık: hemen hemen her gün; bazen: haftada 1-2; nadiren: ayda 1-2 kez) değişkeni ile e-sadakat arasında anlamlı bir fark olup olmadığı araştırılmıştır. Bu kapsamda Kruskall Wallis yöntemi uygulanmış ve analiz neticesinde de, anket yanıtlayıcılarının sosyal paylaşım sitelerindeki havayolu işletmelerinin sayfalarını takip etme sıklıkları ile e-sadakat arasında anlamlı farklılık bulunmuştur $\left(\chi^{2}=109.502, p<0.05\right)$.

Tablo 9'dan da görüleceği üzere, grupların sıra ortalamaları dikkate alındığında; e-sadakat değişkeninde en yüksek ortalamayı, sosyal paylaşım sitelerinde yer alan havayolu işletmelerinin sayfalarını çok sık (hergün mutlaka) takip edenlerin olduğu, onu oldukça sık (hemen hemen hergün) takip edenlerin izlediği görülmektedir.

Tablo 9: Kullanıcıların Havayolu İşletmelerini Sosyal Paylaşım Sitelerinden Takip Etme

Sonucundaki E-sadakatinin, Havayolu İşletmelerinin Sosyal Medya Sitelerindeki Sayfalarının Takip Edilme Sıklığına Göre Farklılaşması

\begin{tabular}{|c|c|c|c|c|c|c|c|}
\hline & Grup & $\mathbf{n}$ & Sira Ort. & sd & $\chi^{2}$ & $\mathbf{p}$ & $\begin{array}{c}\text { Anlamlı } \\
\text { Fark }\end{array}$ \\
\hline \multirow{4}{*}{ E-sadakat } & Çok sık (1) & 121 & 276.48 & \multirow{4}{*}{3} & \multirow{4}{*}{109.502} & \multirow{4}{*}{0.000} & \multirow{4}{*}{$\begin{array}{c}1-3,1-4 \\
2-3,2-4 \\
3-4\end{array}$} \\
\hline & Oldukça sık (2) & 231 & 266.40 & & & & \\
\hline & Bazen (3) & 87 & 148.52 & & & & \\
\hline & Nadiren (4) & 29 & 63.19 & & & & \\
\hline
\end{tabular}

Katılımcıların, havayolu işletmelerinin sosyal paylaşım sitelerindeki sayfalarını takip etme sıklıkları arasında gözlenen anlamlı farkın, hangi sıklıklar arasındaki anlamlı farklara bağlı olarak çıktığını belirleyebilmek için, Mann Whitney U-testi uygulanmıştır. Buna göre; havayolu işletmelerinin sosyal paylaşım sitelerindeki sayfalarını çok sık takip edenler, bazen takip edenlere ve nadiren takip edenlere; oldukça sık takip edenler, bazen takip edenlere ve nadiren takip edenlere; bazen takip edenler ise, nadiren takip edenlere kıyasla farklılık göstermektedir.

\section{BULGULAR VE SONUÇ}

Sosyal paylaşım sitelerinde sayfaları bulunan havayolu işletmelerinin sayfalarındaki esadakati etkileyen faktörleri ölçmek amacıyla araştırma kapsamında toplam 490 kişiye 
anket uygulanmıştır. Anket yanıtlayıcılarının 426'sı Facebook'u, 308'i ise Twitter'ı kullanmaktadır. Bu noktadan hareketle, Türkiye'de en fazla kullanılan sosyal paylaşım siteleri olan Facebook ve Twitter kullanıcılarının görüşleri alınmaya çalışılmıştır. Araştırma kapsamında; THY, Onurair, Pegasus, Atlasjet, Sunexpress, Anadolujet havayolu işletmelerinin sosyal medya sitelerindeki sayfalarının takipçilerine ulaşılmıştır. Anket sonuçlarına göre, araştırmaya katılan yanıtlayıcılar, sosyal mecrada en fazla Anadolujeti, hemen hemen her gün takip etmektedir.

Araştırma kapsamında yapılan anket çalışmasında, e-sadakat ve e-sadakati etkilediği düşünülen değişkenlere yönelik oluşturulan ifadelere verilen cevapların ortalamaları dikkate alındığında; havayolu işletmelerinin sosyal ağ sitelerindeki sayfalarına yönelik esadakat düzeylerinin yüksek olduğu sonucuna ulaşılmıştır. Üye profili hariç, diğer değişkenlere yönelik (sosyal bulunuşluk, etkileşim, değişim maliyeti ve aidiyet duygusu) ifadelere verilen cevapların ortalamaları incelendiğinde, katılımcıların havayolu işletmelerinin sosyal ağ sitelerindeki sayfalarına yönelik olumlu tutumlar sergilediği sonucuna ulaşılmıştır.

Araştırma sonucunda, cinsiyet, yaş ve medeni durum ile e-sadakat arasında anlamlı bir fark tespit edilememiştir.

Havayolu işletmelerinin sosyal ağ sitelerinde yer alan sayfalarına yönelik e-sadakat ile katılımcıların eğitim ve gelir düzeyleri arasında anlamlı farkın olup olmadığı araştırımıştır. Yapılan analizler neticesinde de, e-sadakat ile eğitim ve gelir düzeyi arasında anlamlı farkın bulunduğu sonucuna ulaşılmıştır. Buna göre genel olarak, eğitim ve gelir düzeyi arttıkça, esadakate yönelik ifadelerde de olumlu bir artış olduğu gözlemlenmiştir. Bu sonucun, havayolu ile seyahati tercih edenlerin genel olarak eğitim ve gelir düzeyi yüksek kişilerden ve söz konusu bu kişilerde bilinç düzeyinin, diğer gruplara kıyasla görece daha iyi bir seviyede olması nedeniyle olduğu dile getirilebilir.

Araştırma kapsamında anket soruları yöneltilen katılımcıların internet kullanım süreleri ve sıklığı ile havayolu işletmelerinin sosyal ağ sitelerindeki sayfalarına yönelik e-sadakat değişkeni arasında anlamlı farklılık bulunmuştur. Yapılan analizler, kişilerin internet kullanım süre ve sıklığı arttıkça, e-sadakat seviyesinin de arttığı sonucuna ulaşılmıştır.

Araştırmanın ortaya çıkardığı bir diğer sonuç; sosyal ağ sitelerinde sayfaları bulunan ve ankete dahil edilen katılımcılar tarafından takip edilen havayolu işletmesine göre esadakatin değişime uğramasıdır. Buna göre, Facebook, Twitter gibi sosyal ağlarda sayfaları bulunan havayolu işletmelerinin sayfalarına yönelik e-sadakat değişkeni açısından en yüksek puanı, Anadolu Jet havayolu işletmesi almıştır. Anadolujet havayolu işletmesinin, sosyal paylaşım sitelerindeki sayfalarında e-sadakati oluşturduğu düşünülen değişkenlerin tamamında bu kadar yüksek puanlar almasının nedeni; işletmenin sayfalarında oyunlaştırma sistemini adapte etmesi, kullanıcılarına çeşitli ödüller vermesi, bilgilendirici küçük notlar paylaşmak suretiyle, kullanıcılarının eğlenerek sayfalarında vakit geçirmesi olduğu düşünülebilir.

Araştırma kapsamında, sosyal paylaşım sitelerinde sayfaları olan havayolu işletmeleri sayfalarının takip edilme sıklığı ile e-sadakat arasında anlamlı bir ilişki bulunmuş ve beklendiği gibi; katılımcıların, havayolu işletmelerinin sosyal ağ sitelerindeki sayfalarını 
kullanım / ziyaret etme sıklığı arttıkça, bu sayfalara yönelik e-sadakat seviyelerinin de arttığı görülmüştür.

Araştırma kapsamında yapılan anket çalışması neticesinde, sosyal paylaşım sitelerinde yer alan havayolu işletmelerinin sayfalarına yönelik e-sadakati etkileyen ve aralarındaki ilişkiyi ortaya koymak amacıyla, bağımlı değişken olan e-sadakat ile bağımsız değişkenler olan sosyal bulunuşluk, etkileşim, değişim maliyeti, üye profili ve aidiyet duygusu arasında korelasyon analizi yapılmıştır. Analiz sonucunda, sosyal paylaşım sitelerinde yer alan havayolu işletmelerinin sayfalarına yönelik e-sadakati en fazla açıklayan ve aralarında pozitif, yüksek düzeyde ilişki olan değişken değişim maliyeti olup onu, aidiyet duygusu takip etmektedir. Çalışmaya konu olan ve e-sadakati etkilediği düşünülen değişkenlerden, sosyal bulunuşluk, etkileşim ve üye profili ile e-sadakat arasında pozitif ve orta düzeyde bir ilişki tespit edilmiştir.

Elde edilen sonuçlar neticesinde, havayolu işletmelerinin sosyal medya sitelerindeki sayfalarına yönelik e-sadakati sağlayabilmeleri için, kullanıcıların sosyal paylaşım sitelerinde yer alan havayolu işletmelerinin sayfasından başka bir havayolu işletmesinin sayfasını takip etmesi neticesinde manevi olarak ciddi maliyetlerde karşı karşıya kalmasına zemin oluşturacak niteliklerle donatması faydalarına olabilecektir. Diğer bir ifadeyle, havayolu işletmelerinin sosyal paylaşım sitelerindeki sayfalarının değişim maliyetlerini yüksek seviyede tutacak, hizmet ve iletişim sunmalıdır. Ayrıca havayolları, sosyal paylaşım sitelerindeki sayfalarında, üyelerinin insan sıcaklık ve duyarlıı̆̆ını barındıran, takipçilerinde sosyalleşme hissi uyandıran bir ortam yaratmalı; takipçilerinin bu sayfalarda vakit geçirirken, kendisini bu sosyal gruba ait hissetmelerini sağlayacak iletişim ortamını oluşturmalıdır.

\section{KAYNAKÇA}

Akar, E. (2004), Sanal Ortamda Müşteri İlişkileri Yönetimi ve THY Web Sitesinin Müşteri Memnuniyeti Üzerine Etkisi. Yayınlanmamış Doktora Tezi. Afyon: Afyon Kocatepe Üniversitesi.

Akar, E. (2010), Sosyal Medya Pazarlaması: Sosyal Webde Pazarlama Stratejileri. Ankara: Efil Yayınevi.

Aksoy, R. (2006), İnternet Ortamında Pazarlama. Ankara: Seçkin Yayıncılık.

Al-Agaga, A. M. ve Nor, K. M. (2012), Factors That Influence E-loyalty of Internet Banking Users. International Journal of Electronic Commerce Studies, 3 (2), p. 297-304.

Alikılıç, Ö., Gülay, G. ve Binbir, S. (2013), Kullanımlar ve Doyumlar Kuramı Çerçevesinde Facebook Uygulamalarının İncelenmesi: Yaşar Üniversitesi Öğrencileri Üzerine Bir Araştırma. İletişim Kuram ve Araştırma Dergisi, 37 (Güz 2013), p. 40 - 67.

Al-Maghrabi, T., Basahel, A. ve Kamal, M. (2011), What Drives Consumers' E-Loyalty to Airlines Website? Conceptual Framework and Managerial Implications in the Case of Saudi Arabia. European, Mediterranean \& Middle Eastern Conference on Information Systems 2011 isimli konferansta sunulan bildiri. http://www.iseing.org/emcis/EMCISWebsite/EMCIS2011\%20Proceedings/SCI9.pdf, Erişim Tarihi: 05.09.2011.

Anderson, R. E. ve Srinivasan, S. S. (2003), E-Satisfaction and E-Loyalty: A Contingency Framework. Psychology \& Marketing, 20(2), p. 123-138.

Asim, M. ve Hashmi, Y. (2005), E-loyalty: Companies Secret Weapon on the Web. Yayınlanmamış Yüksek Lisans Tezi. Luleå: Luleå University of Technology.

Atalık, Ö. (2005), Havayolu İşletmeleri Örneğinde İşletme İmajının Havayolu İşletmesi Tercihlerine ve müşteri Bağlılığına Olan Etkisinin Belirlenmesine Yönelik Bir Araştırma. Akademik Bakış, 7. http://www.akademikbakis.org/pdfs/7/Anadolu.pdf, Erişim Tarihi: 28.04.2009. 
Aydın, S, Özcan, M ve Yücel, R. (2007), Türk GSM Sektöründe Abonelerin Sadakat Tutumu ve Değiştirme Maliyetinin Rolü. Süleyman Demirel Üniversitesi İktisadi ve İdari Bilimler Fakültesi,12 (2), p. 219-234.

Balabanis, G., Reynolds, N. ve Simintiras, A. (2006), Bases of E-Store Loyalty: Perceived Switching Barriers and Satisfaction. Journal of Business Research, 59, p. 214-224.

Ballantine, P.W. (2005), Effects of Interactivity and Product Information on Consumer Satisfaction in an Online Retail Setting. International Journal of Retail \& Distribution Management, 33 (6), p. 461 - 471.

Barutçugil, ì. (2010), Müşteri bağıılı̆ını yaratmak. http://www.rcbadoor.com/makalevekitaplar/makaleler/satis/new page 23.htm, Erişim Tarihi: 21.06.2011

Bulunmaz, B. (2011), Otomotiv Sektöründe Sosyal Medyanın Kullanımı ve FIAT Örneği. Global Media Journal Turkish Edition, 2(3), p. 19-50.

Büyüköztürk, Ş. (2010), Sosyal Bilimler İçin Veri Analizi El Kitabı, Türkiye: Pegem Akademi.

Cao, H., Jiang, J., Oh, L.B., Li, H., Liao, X. ve Chen, Z. (2013), A Maslow's Hierarchy of Needs Analysis of Social Networking Services Continuance. Journal of Service Management, 24(2), p. 170-190.

Chang, Y.H. ve Chen, F.Y. (2007), Relational Benefits, Switching Barriers and Loyalty: A Study of Airline Customers in Taiwan. Journal of Air Transport Management, 13 (2), p. $104-109$.

Chang, H. H. ve Chen, S. W. (2008), The Impact of Customer Interface Quality, Satisfaction and Switching Costs on E-Loyalty: Internet Experience as a Moderator. Computers in Human Behavior, 24, p. 2927-2944.

Choi, D. ve Kim, J. (2004), Why People Continue to Play Online Games: In Search of Critical Design Factors to Increase Customer Loyalty to Online Contents. Cyber Psychology \& Behavior, 7(1), p. 11-24.

Chung, J.Y. ve Buhalis, D. (2008), Web 2.0: A Study of Online Travel Community. Information and Communication Technologies in Tourism 2008 (Yayına hazırlayanlar: P. O'Connor vd.). Vienna: Springer, p. 70-81.

Coverdale, T. S. (2010), The Influence of Social Presence on E-Loyalty in Women Online Shoppers: An Application of The Social Identity Approach to Website Design. Yayınlanmamış Doktora Tezi. Baltimore: Morgan State University.

Currás-Pérez, R., Ruiz-Mafé, C. ve Sanz-Blas, S. (2013), Social Network Loyalty: Evaluating the Role of Attitude, Perceived Risk and Satisfaction. Online Information Review, 37(1), p. 61-82.

Cyr, D., Hassanein, K., Head, M. ve Ivanov, A. (2007), The Role of Social Presence in Establishing Loyalty in EService Environments. Interacting with Computers, 19, p. 43-56.

Çırpan, H. (2011), Değer odaklı yönetim.

http://www.eflatun.com.tr/makaleler/hcirpan degerodakli yonetim.pdf, Erişim Tarihi: 21.06.2011.

Çiftçi, S. ve Koçak, A. (2009), Aktif - Pasif Kulaktan Kulağa İletişim ve Aktif Kulaktan Kulağa Illetişimi Etkileyen Faktörler Üzerine Bir Çalışma. Ankara Üniversitesi Siyasal Bilgiler Fakültesi Dergisi, 64(4), p. 101-116.

Damásio, M.J., Henriques, S. ve Costa, C. (2012), Belonging to a Community: The Mediation of Belonging. Observatorio (OBS*) Journal, Special issue, p. 127-146.

Devaraj, S., Fan, M. ve Kohli. R. (2003), E-Loyalty - Elusive Ideal or Competitive Edge? Communications of the ACM, 46 (9), p. 184-191.

Elkhani, N., Soltani, S. ve Jamshidi, M.H.M. (2014), Examining a Hybrid Model for E-Satisfaction and E-Loyalty to E-Ticketing on Airline Websites. Journal of Air Transport Management, 37 (2014), p. 36-44.

Eng, T. ve Kim, E. J. (2006), An Examination of the Antecedents of E-Customer Loyalty in a Confucian Culture: The case of South Korea. The Service Industries Journal, 26(4), p. 437-458.

Eröz, S.S. ve Doğdubay, M. (2012), Turistik Ürün Tercihinde Sosyal Medyanın Rolü ve Etik i̇lişkisi. Dokuz Eylül Üniversitesi İktisadi ve İdari Bilimler Fakültesi Dergisi, 27(1), p. 133-157.

Forgas, S., Palau, R., Sánchez, J. ve Huertas-García, R. (2012), Online Drivers and Offline Influences Related to Loyalty to Airline Websites. Journal of Air Transport Management, 18(2012), p. 43-46.

Golletz, M. ve Ogheden, P. (2010), Customer Returns in E-Commerce \& Consumers Interaction via Social Media. Yayınlanmamış Yüksek Lisans Tezi. Borås: University of Borås. 
Gommans, M., Krishnan, K. S. ve Scheffold, K. B. (2001), From Brand Loyalty to E-Loyalty: A Conceptual Framework. Journal of Economic and Social Research, 3(1), p. 43-58.

Guo, Y. M. ve Liu, C. (2010), Loyalty of Web 2.0 Sites: The Role of Sense of Belonging. Pasific Asia Conference on Information System konferansında sunulan bildiri. http://www.pacis-net.org/file/2010/S24-01.pdf, Erişim Tarihi: 06.04.2011.

Hacıefendioğlu, Ş. (2010), Sosyal Paylaşım Sitelerinde Üye Bağlılığı Üzerine Bir Araştırma. Kocaeli Üniversitesi Sosyal Bilimler Enstitüsü Dergisi, 20, p. 59-71.

Hamid, N. R. A. ve McGrath, G. M. (2005), The Diffusion of Internet Interactivity on Retail Web Sites. Communications of the IIMA, 5(2), p. 35-46.

Heller, J. ve Engelke, N. (2010), How to Keep Your Customer Loyal within Today's Online Business? Yayınlanmamış Yüksek Lisans Tezi. Borås: University of Borås.

Jin, B., Park, J. Y. ve Kim, J. (2008), Cross-Cultural Examination of the Relationships Among firm Reputation, ESatisfaction, E-Trust, and E-Loyalty. International Marketing Review, 25(3), p. 324-337.

İlban, M.O. ve Kaşlı, M. (2013), Jenerasyon Y Tüketicileri İçin Bağlılık Modeli: Havayolu Şirketleri Üzerine Bir Araştırma. İstanbul Üniversitesi İşletme Fakültesi Dergisi, 42(1), p. 133-152.

İşler, S. ve Andiç, B. (2011), Ağdaki Olta Balıkları ve Viral Pazarlamacılar. XVI. Türkiye'de internet konferansı'nda sunulan bildiri. http://inet-tr.org.tr/inetconf16/bildiri/42.pdf, Erişim Tarihi: 13.02.2012.

Lin, H. ve Wang, Y. (2006), An Examination of the Determinants of Customer Loyalty in Mobile Commerce Contexts. Information and Management, 43, p. 271-282.

Lin, H. (2008), Determinants of Successful Virtual Communities: Contributions from System Characteristics and Social Factors. Information \& Management, 45, p. 522-527.

Lin, N., Chung, I. ve Skytech (2008), The Impacts of Relationship Marketing on Relationship Quality and E-Loyalty - Taking Internet - Based Search-Experience-Credence Products as an Example. International Conference on Business and Information isimli konferansta sunulan bildiri. http://academicpapers.org/ocs2/session/papers/d1/322.doc, Erişim Tarihi: 06/04/2011.

Llach, J., Marimon, F., Alonso-Almeida, M.M. ve Bernardo, M. (2013), Determinants of Online Booking Loyalties for the Purchasing Of Airline Tickets. Tourism Management, 35(2013), p. 23-31.

Maurer, C. ve Wiegmam, R. (2011), Effectiveness of Advertising on Social Network Sites: A Case Study on Facebook. Information and Communication Technologies in Tourism 2011 (Yayına hazırlayanlar: R. Law vd.). Vienna: Springer Vienna, p. 485 - 498.

Mouakket, S. ve Al-hawari, M.A. (2012), Examining the Antecedents of E-Loyalty Intention in an Online Reservation Environment. Journal of High Technology Management Research, 23(2012), p. 46-57.

Nusair, K.K., Bilgihan, A., Okumus, F. ve Cobanoglu, C. (2013), Generation Y Travelers' Commitment to Online Social Network Websites. Tourism Management, 35 (2013), p. 13-22.

Oliver, R. L. (1999), Whence Consumer Loyalty. The Journal of Marketing, 63, p. 33-44.

Olpak, Y. Z. ve Çakmak, E. K. (2009), E-Öğrenme Ortamları için Sosyal Bulunuşluk Ölçeğinin Uyarlama Çalışması. Yüzüncü Yıl Üniversitesi Eğitim Fakültesi Dergisi, 5(1), p. 142-160.

Özer, L. ve Gülpınar, S. (2005), Hizmet Sektöründe Tüketicilerin Algıladıkları Riskler: Havayolları Sektöründe Bir Araştırma. Ticaret ve Turizm Eğitim Fakültesi Dergisi, 1, p. 49-63.

Pietro, D.L., Virgilio, D.F. ve Pantano, E. (2012), Social Network for the Choice of Tourist Destination: Attitude and Behavioural Intention. Journal of Hospitality and Tourism Technology, 3(1), p. 60-76.

Pulvirenti, M. ve Jung, T. (2011), Impact of Perceived Benefits of Social Media Networks on Web Quality and ESatisfaction. Information and Communication Technologies in Tourism 2011(Yayına hazırlayanlar: R. Law vd.). Vienna: Springer Vienna, p. 513-524.

Sharma, N. ve Patterson, P. G. (2000), Switching Costs, Alternative Attractiveness and Experience as Moderators of Relationship Commitment in Professional, Consumer Services. International Journal of Service Industry Management,11(5), p. 470-490. 
Shipps, B. ve Phillips, B. (2013), Social Networks, Interactivity and Satisfaction: Assessing Socio-Technical Behavioral Factors as an Extension to Technology Acceptance. Journal of Theoretical and Applied Electronic Commerce Research, 8 (1), p. 35-52.

Sledgianowski, D. ve Kulviwat, S. (2009), Using Social Network Sites: The Effects of Playfulness, Critical Mass and Trust in a Hedonic Context. Journal of Computer Information Systems, Summer 2009, p. 74-83.

Smillie, K. (2010), Nielsen/facebook study: Social ads perform better. http://blog.socialmedia.com/, Erişim Tarihi: 15.03.2011.

Smith, E. R. (2000), The Seven Steps to Designing an E-Loyalty Strategy. Brandweek. http://findarticles.com/p/articles/mi m0BDW/is 45 41/ai 67541935/, Erişim Tarihi: 22.02.2010.

Souitaris, V. ve Balabanis, G. (2007), Tailoring Online Retail Strategies to İncrease Customer Satisfaction and Loyalty. Long Range Planning, 40, p. 244-261.

Srinivasan, S.S., Anderson, R ve Ponnavalu, K. (2002), Customer Loyalty in E-Commerce: An Exploration of Its Antecedents and Consequences. Journal of Retailing, 78, p. 41-50.

Stelzner, M.A. (2013), 2013 Social Media Marketing Industry Report: How Marketers are Using Social Media to Grow their Businesses. Social Media Examiner. http://www.socialmediaexaminer.com/SocialMediaMarketingIndustryReport2013.pdf, Erişim Tarihi: 03.02.2014.

THY Sosyal medya, 2012. www.sosyalmedya.co/thy-roportaj/30/12/2011, Erişim Tarihi: 15.03.2012.

Ünlü, İ. (2010), Sosyal Medyanın Kim Neresinde? http://www.ismailunlu.com/sosyal-medyanin-kim-neresinde, Erişim Tarihi: 21.06.2011.

Vural, Z. B. A. ve Bat, M. (2010), Yeni Bir İletişim Ortamı Olarak Sosyal Medya: Ege Üniversitesi İletişim Fakültesine Yönelik Bir Araştırma. Journal of Yaşar University, 20(5), p. 3348-3382.

Wu, J.J. ve Chang, Y.S. (2005), Towards Understanding Members' Interactivity, Trust, and Flow in Online Travel Community. Industrial Management \& Data Systems, 105 (7), p. 937 - 954.

http://eticaretmag.com/sosyal-medya-ve-mobil-istatistikleri, Erişim Tarihi: 01.04.2014.

http://www.havayolu101.com/2012/05/25/twitter-ve-havayolu-sirketleri-2/, Erişim Tarihi: 17.08.2012.

http://www.kariyer.net/kariyerrehberi/kariyerRehberiDetay.kariyer?kn=611, Erişim Tarihi: 21.06.2011.

http://www.mienotes.com/2009/10/adalet-aidiyet-ve-sadakat/, Erişim Tarihi: 21.06.2011. 